\title{
Influence of Maternal Satisfaction with the Dentist in Children's Oral Care: Cross-Sectional Study
}

\author{
Influencia de la Satisfacción Materna con el Dentista \\ en la Salud Oral del Niño: Estudio Transversal
}

\begin{abstract}
Lilian Rigo1; Monica Gnoatto1; José Lucas Sani de Alcântara Rodrigues²; Walbert de Andrade Vieira³; Vinícius Henrique Ferreira Pereira-de-Oliveira ${ }^{4}$ \& Luiz Renato Paranhos ${ }^{4}$
\end{abstract}

RIGO, L.; GNOATTO, M.; RODRIGUES, J. L. S. A.; VIEIRA, W. A.; PEREIRA-DE-OLIVEIRA, V. H. F. \& PARANHOS, L. R. Influence of maternal satisfaction with the dentist in children's oral care: cross-sectional study. Int. J. Odontostomat., 13(2):172179, 2019.

ABSTRACT: Childhood is a period of life when the human being is constantly going through progressive steps of psychosocial, physical, and mental development. The quality of hygiene habits of family members will be reflected on the characteristics and attitudes of children, which significantly increases the responsibility of the family in oral hygiene education. The present study aimed to observe the influence of maternal satisfaction with the dentist in children's oral care. This is a cross-sectional design, which sample included 100 mothers from a city in Southern Brazil. From a questionnaire prepared for this purpose and adapted from previous research, the mothers were interviewed from January to July 2015 . The results presented showed that most mothers work outside the home $(46.4 \%)$ but monitor their children during toothbrushing (50.7 $\%)$. For most mothers, the dentist represents satisfaction (37.1\%) and the main reason for seeking the dentist is oral health $(44.3 \%)$. It was found that mothers who encourage their children to use dental floss and monitor them during toothbrushing are the mothers who feel satisfied with the dentist $(P<0.05)$. In addition, mothers know that caries is a disease and its occurrence is related to diet habits, however, they add chocolate milk and sugar to their children's bottle. Thus, it was concluded that satisfaction with the dentist influences mothers on oral hygiene habits adopted by their children regarding the use of dental floss and toothbrushing monitoring.

KEY WORDS: dentists, mothers, oral health, oral hygiene, patient satisfaction.

\section{INTRODUCTION}

New concepts have been developed from the assumption that education creates healthy life habits, which resulted in the need for an early action concerning health maintenance even before disease prevention. General health quality, especially oral health, is intrinsically associated with the adoption of a healthy lifestyle by the whole family. The concepts of healthcare and prevention education are essential factors for oral health maintenance (da Siva et al., 2013). Socioeconomic conditions, as well as good physical and mental health, are determinant factors in the health-disease process. It is important for the population to appropriate the knowledge so that trained professionals may transfer this knowledge clearly and cohesively, in order to aid the population in obtaining healthy habits (da Silva \& Forte, 2009).

Childhood is a period of life when the human being is constantly going through progressive steps of psychosocial, physical, and mental development. The quality of hygiene habits of family members will be reflected on the characteristics and attitudes of children, which significantly increases the responsibility of the family in oral hygiene education. Therefore, adults need to be motivated, receptive, and cooperative, as well as to present knowledge and healthy habits (Campos et al., 2010). Making parents think about their role as

\footnotetext{
${ }^{1}$ Dental School, Faculdade Meridional - IMED, Passo Fundo, RS, Brazil.

2 Department of Dentistry, State University of Feira de Santana, Feira de Santana, BA, Brazil.

${ }^{3}$ Department of Dentistry, Federal University of Sergipe, Aracaju, SE, Brazil.

${ }^{4}$ Departament of Preventive and Social Dentistry, School of Dentistry, Federal University of Uberlândia, Minas Gerais, Brazil.
} 
caregivers regarding the conduct of their children is the first step for successfully reflecting on healthy habits (Cruz et al., 2004; Oliveira \& Forte, 2011).

Postponing dental prenatal has become an incorrect and ordinary practice, which favors the aggravation of oral problems and the precariousness of oral conditions of both mother and child. In this context, oral health education for pregnant women should be highlighted, considering that mothers play a major role in the household, acting as education multipliers, forming opinions, and building the character and consciousness of their children (Cabral et al., 2013). Addressing the factors that influence the oral health of children is useful for the development and implementation of additional public health actions focusing on the behavior of children and their parents, in an effort to provide good oral health and better quality of life (Castilho et al., 2013).

Determining actions focused on mothers and children, in the first years of life, becomes an interesting strategy to promote oral health within a multiprofessional and intersectoral approach involving public health workers and the families that live in the coverage area of the Family Health Team (Oliveira \& Forte). By the current service model, which seeks oral health promotion and prevention, it is imperative for dentists to discuss this concept with mothers, so they become aware and create proper oral health habits in their families.

Thus, the adoption of poor habits by those who are multipliers of knowledge and attitudes creates a vicious cycle of unsatisfactory practices and perpetuates diseases and oral health aggravations. Therefore, the existence of family education on proper oral hygiene is highlighted for successful oral health. Thus, the present study aimed to observe the influence of maternal satisfaction with the dentist in children's oral care.

\section{MATERIAL AND METHOD}

Ethical considerations. This study was approved by the Research Ethics Committee in Human Beings under protocol 689.475 and CAAE 31581214.8.0000.5319, complying with ethical and legal norms. The mothers who participated in the research consented to do so by signing the Informed Consent Form.
Sample qualification and study location. The present study has a quantitative approach and crosssectional design. The study was developed in a Basic Healthcare Unit (BHU) with the Family Health Strategy (FHS) of the city of Marau, Rio Grande do Sul, Brazil, which was determined by convenience because of their full professional team and downtown location. The study was performed from January to July, 2015.

The population of the city corresponds to 40,147 inhabitants and it is located in the North region of Rio Grande do Sul. The city is $100 \%$ covered by the Family Health Strategy (FHS) with twelve units built to serve the population, one Psychosocial Care Center, and one Medical Specialties Unit. The FHS structures include six dentists, sixteen nurses, seventeen physicians (General Practice, Gynecology, Pediatrics, Psychiatry, and Mental health specialists), and one nutritionist (IBGE, 2016). Thus, the present study was performed in the FHS of the city's Progresso neighborhood for being an accessible and central location. The team includes one general practitioner, one dentist, one oral health assistant, one nurse, one nurse technician, one psychologist, and four full-time health agents.

According to data from the Instituto Brasileiro de Geografia e Estatística (IBGE) the number of women aged 15 to 39 years in the city of the study is 7,876 . It is likely that women in the age group mentioned have children, according to the age established in the research. The sample calculation for the target population, with parameters of $5 \%$ sample error, $95 \%$ confidence interval, and a maximum of $50 \%$ prevalence of characteristic of interest, would result in a sample of 367 women. As exclusion criteria, mothers with children younger than 3 years old and older than 12 years old were excluded from the study. Thus, 267 mothers were not included in the final sample, and only the mothers who matched the criteria determined by the present study remained, resulting in 110 mothers. However, there was a loss of responses from 10 mothers $(9 \%)$, totaling in a sample of 100 mothers who accepted to participate in the study. The method for sample selection may have presented limitations regarding generalization; however, the authors considered that it satisfactorily represented the opinion of mothers who attended the BHU of the city studied.

Procedures and instruments for data collection. Data collection was performed through information reported by the mothers when filling a self-application questionnaire, performed in the months of collection. In order to validate data collection and estimate the 
time spent filling the form, a pilot test was performed before the interview ( $n=10$; not included in the study), with special attention given to relevant aspects regarding reliability, content, and research application. After this pilot test, the script was restructured and a final version of the instrument was created.

The variables analyzed were grouped in socioeconomic characteristics, knowledge and attitude concerning oral hygiene of children, as well as diet habits and experience of the mother with the dentist. The questionnaire used was adapted from other studies (Faustino-Silva et al., 2008; Oliveira \& Forte).

Data analysis. Data were electronically processed with the Statistical Package for Social Science (SPSS) software, version 20.0. Then, descriptive and inferential statistical data analyses were performed from the information obtained by the data collection instrument.

Table I. Distribution of variables of perception on oral hygiene habits and diet habits of children.

\begin{tabular}{|c|c|c|}
\hline Variables & $\mathrm{n}(100)$ & $100 \%$ \\
\hline \multicolumn{3}{|l|}{ Caries considered as a disease } \\
\hline No & 24 & 17.1 \\
\hline Yes & 76 & 54.3 \\
\hline \multicolumn{3}{|l|}{ Number of toothbrushing per day by children } \\
\hline Once a day & 15 & 10.7 \\
\hline More than twice a day & 85 & 60.7 \\
\hline \multicolumn{3}{|l|}{ Use of dental floss by children } \\
\hline No & 26 & 18.6 \\
\hline Yes & 74 & 52.9 \\
\hline \multicolumn{3}{|l|}{ Oral hygiene of children when they were babies } \\
\hline Moistened gauze & 70 & 50.0 \\
\hline \multicolumn{3}{|l|}{ Age children stopped being bottle-fed } \\
\hline 1 year old & 28 & 20.0 \\
\hline 2 to 6 years old & 72 & 51.4 \\
\hline \multicolumn{3}{|l|}{ Bottle content } \\
\hline Warm milk & 32 & 22.9 \\
\hline Warm milk with sugar & 15 & 10.7 \\
\hline Warm milk with chocolate & 53 & 37.9 \\
\hline \multicolumn{3}{|c|}{ Age children started to perform oral hygiene by themselves } \\
\hline 1 to 3 years old & 34 & 24.3 \\
\hline After 3 years old & 66 & 47.1 \\
\hline \multicolumn{3}{|l|}{ Advising on toothbrushing } \\
\hline Brush teeth lightly & 83 & 59.3 \\
\hline Brush teeth strongly & 17 & 12.1 \\
\hline \multicolumn{3}{|l|}{ Mother's monitoring during toothbrushing } \\
\hline No & 29 & 20.7 \\
\hline Yes & 71 & 50.7 \\
\hline \multicolumn{3}{|l|}{ Reason for no monitoring, if this is the case } \\
\hline Lack of time & 64 & 45.7 \\
\hline Thinks children can toothbrush by themselves & 36 & 25.7 \\
\hline \multicolumn{3}{|l|}{ Strictness with toothbrushing schedule } \\
\hline No & 18 & 12.9 \\
\hline Yes & 82 & 58.6 \\
\hline \multicolumn{3}{|l|}{ Relation of food to caries occurrence } \\
\hline No & 11 & 7.9 \\
\hline Yes & 89 & 63.6 \\
\hline
\end{tabular}

For the descriptive analysis, all variables were described in a table with relative and absolute values, in order to verify frequency distributions found in data from the mothers' responses. Pearson's chi-square test was used to assess the association between the dependent variable and independent variables, with 5 $\%$ significance level and $95 \%$ confidence interval $(P<$ 0.05).

For the inferential analysis, the variable "satisfaction of the dentist" was determined, and its categories were divided into two groups according to data frequency distribution: dissatisfaction (fear/pain/ cost) and satisfaction. The remaining independent variables were divided into three groups: 1. Sociodemographic variables (age group, marital status, occupation, level of education, family income, number of people in the household); 2. Variables of perception and oral hygiene habits of children (caries considered as a disease, number of tooth brushing per day by children, use of dental floss by children, oral hygiene of children when they were babies, age children stopped being bottle-fed, Bottle-fed content, age children started to perform oral hygiene by themselves, advising on toothbrushing, mother's monitoring during toothbrushing, reason for no monitoring if this is the case, strictness with toothbrushing schedule, relation of food to the occurrence of caries); 3 . Variables of experience with the dentist (last visit to the dentist, quitting treatment with a dentist, satisfaction of the dentist, main reason for visiting the dentist, and feelings during treatment with a dentist).

\section{RESULTS}

The profile of mothers showed that most of them are married (52.9 $\%)$, work outside the home (46.4\%), are $31-39$ years old $(31.4 \%)$, and completed high school (25.7\%). Most of them live with 3 or 4 additional people in the household (27.9\%).

Table I shows their children's oral hygiene habits, given that 54.3 
Table II. Distribution of variables of mothers' experience with the dentist.

\begin{tabular}{lcc}
\hline Variables & $\mathrm{n} \mathrm{(100)}$ & $100 \%$ \\
\hline Last visit to the dentist & 38 & 27.1 \\
6 months ago & 62 & 44.3 \\
More than 6 months & & \\
Quitting treatment with a dentist & 60 & 42.9 \\
No & 40 & 28.6 \\
Yes & & \\
Representation of the dentist & 15 & 10.7 \\
Fear & 13 & 9.3 \\
Pain & 20 & 14.3 \\
Cost & 52 & 37.1 \\
Satisfaction & & \\
Main reason for visiting the dentist & 29 & 20.7 \\
Fear & 62 & 44.3 \\
Oral health & 9 & 6.4 \\
Esthetics & & \\
Feelings during treatment with a dentist & 22 & 22.0 \\
Relaxed & 78 & 78.0 \\
Anxious &
\end{tabular}

$\%$ considers caries as a disease, and $63.6 \%$ believes the occurrence of caries is related to diet habits. Children brushed their teeth more than twice per day $(60.7 \%)$ and use dental floss $(52.9 \%)$. Most of the children (51.4\%) were bottle-fed up to 2 and 6 years old. Regarding toothbrushing of children, $59.3 \%$ of mothers advise their children to lightly brush their teeth, $58.6 \%$ is strict with toothbrushing schedule, and $50.7 \%$ monitors their children during toothbrushing. Children started performing oral hygiene by themselves from 3 years old in $47.1 \%$ of the sample. Table II shows the variables of mothers regarding experience with the dentist, considering that $44.3 \%$ had visited the dentist for over 6 months and $42.9 \%$ had already quit at least one dental treatment. For most mothers, the dentist represents satisfaction $(37.1 \%)$ and the main reason for visits is oral health $(44.3 \%)$, however, a large portion of the mothers feel anxious during treatment $(55.7 \%)$.

Table III. Bivariate analysis of sociodemographic variables and relationship of mothers with the satisfaction of dentist.

\begin{tabular}{|c|c|c|c|c|c|c|c|}
\hline \multirow[b]{3}{*}{$\begin{array}{l}\text { INDEPENDENTS VARIABLES } \\
\text { Marital status }\end{array}$} & \multicolumn{7}{|c|}{ Satisfaction of the dentist } \\
\hline & \multicolumn{2}{|c|}{ Dissatisfaction } & \multicolumn{2}{|c|}{ Satisfaction } & \multicolumn{3}{|l|}{ TOTAL } \\
\hline & $\mathrm{n}$ & $\%$ & $\mathrm{n}$ & $\%$ & $\mathrm{n}$ & $\%$ & $p$ \\
\hline Single & 11 & 22.9 & 10 & 19.2 & 21 & 21 & 0.171 \\
\hline Married & 33 & 68.8 & 41 & 78.8 & 74 & 74 & \\
\hline Separated/Divorced & 4 & 8.3 & 1 & 1.9 & 5 & 5 & \\
\hline TOTAL & 48 & 100 & 52 & 100 & 100 & 100 & \\
\hline Occupation & & & & & & & 0.238 \\
\hline Housewife & 19 & 39.6 & 16 & 30.8 & 35 & 35 & \\
\hline Works outside the home & 29 & 60.4 & 36 & 69.2 & 65 & 65 & \\
\hline TOTAL & 48 & 100 & 52 & 100 & 100 & 100 & \\
\hline Level of education & & & & & & & 0.124 \\
\hline Up to $8^{\text {th }}$ grade & 17 & 35.4 & 17 & 32.7 & 34 & 34 & \\
\hline High school & 21 & 43.8 & 15 & 28.8 & 36 & 36 & \\
\hline College/University & 10 & 20.8 & 20 & 38.5 & 30 & 30 & \\
\hline TOTAL & 48 & 100 & 52 & 100 & 100 & 100 & \\
\hline Family income & & & & & & & 0.532 \\
\hline 1 minimum wage & 16 & 33.3 & 14 & 26.9 & 30 & 30 & \\
\hline 2 to 3 minimum wages & 21 & 43.8 & 21 & 40.4 & 42 & 42 & \\
\hline 4 minimum wages or more & 11 & 22.9 & 17 & 32.7 & 28 & 28 & \\
\hline TOTAL & 48 & 100 & 52 & 100 & 100 & 100 & \\
\hline Number of people in the household & & & & & & & 0.082 \\
\hline Up to 3 people & 19 & 39.6 & 20 & 38.5 & 39 & 39 & \\
\hline 4 people & 15 & 31.3 & 24 & 46.2 & 39 & 39 & \\
\hline 5 or more people & 12 & 29.2 & 8 & 14.5 & 22 & 22 & \\
\hline TOTAL & 48 & 100 & 51 & 100 & 100 & 100 & \\
\hline Age & & & & & & & 0.274 \\
\hline 20-30 years old & 19 & 39.6 & 13 & 25 & 32 & 32 & \\
\hline $31-39$ years old & 18 & 37.5 & 26 & 50 & 44 & 44 & \\
\hline $40-55$ years old & 11 & 22.9 & 13 & 25 & 24 & 24 & \\
\hline TOTAL & 48 & 100 & 52 & 100 & 100 & 100 & \\
\hline Caries considered as a disease & & & & & & & 0.497 \\
\hline No & 11 & 22.9 & 13 & 25 & 24 & 24 & \\
\hline Yes & 37 & 77.1 & 39 & 75 & 76 & 76 & \\
\hline TOTAL & 48 & 100 & 52 & 100 & 100 & 100 & \\
\hline Relation of food to caries occurrence & & & & & & & 0.218 \\
\hline No & 7 & 14.6 & 4 & 7.7 & 11 & 11 & \\
\hline Yes & 41 & 85.4 & 48 & 92.3 & 89 & 89 & \\
\hline TOTAL & 48 & 100 & 52 & 100 & 100 & 100 & \\
\hline
\end{tabular}


The inferential analysis showed the associations between independent variables and the outcome variable "satisfaction of the dentist", according to Table III and Table IV. Thus, there was a statistically significant relation observed between the outcome variable and the use of dental floss $(P=0.011)$, showing that mothers who encouraged their children to use dental floss are the ones who feel satisfied with the dentist $(76 \%)$. There was also statistical significance regarding the outcome variable and the monitoring of children during toothbrushing $(\mathrm{P}=$ 0.021 ), where $80.8 \%$ of mothers who feel satisfied with the dentist do such monitoring (Table IV).

Table IV. Bivariate analysis oral hygiene habits variables of children and relationship of mothers with the satisfaction of dentist.

\begin{tabular}{|c|c|c|c|c|c|c|c|}
\hline \multirow{3}{*}{ INDEPENDENTS VARIABLES } & \multicolumn{7}{|c|}{ Satisfaction of the dentist } \\
\hline & \multicolumn{2}{|c|}{ Dissatisfaction } & \multicolumn{2}{|c|}{ Satisfaction } & \multicolumn{2}{|c|}{ TOTAL } & \multirow[b]{2}{*}{$P$} \\
\hline & $\mathrm{n}$ & $\%$ & $\mathrm{n}$ & $\%$ & $\mathrm{n}$ & $\%$ & \\
\hline Number of toothbrushing per day by children & & & & & & & 0.432 \\
\hline Once a day & 8 & 16.7 & 7 & 13.5 & 15 & 15 & \\
\hline More than twice a day & 40 & 83.3 & 45 & 86.5 & 85 & 85 & \\
\hline TOTAL & 48 & 100 & 52 & 100 & 100 & 100 & \\
\hline Use of dental floss by children & & & & & & & ${ }^{*} 0.011$ \\
\hline No & 18 & 37.5 & 8 & 15.4 & 26 & 26 & \\
\hline Yes & 30 & 62.5 & 44 & 84.6 & 74 & 74 & \\
\hline TOTAL & 48 & 100 & 52 & 100 & 100 & 100 & \\
\hline $\begin{array}{l}\text { Oral hygiene of children when they were } \\
\text { babies }\end{array}$ & & & & & & & 0.102 \\
\hline Moistened gauze & 37 & 77.1 & 33 & 63.5 & 70 & 70 & \\
\hline Toothpaste & 11 & 22.9 & 19 & 36.5 & 30 & 30 & \\
\hline TOTAL & 48 & 100 & 52 & 100 & 100 & 100 & \\
\hline Age children stopped being bottle-fed & & & & & & & 0.086 \\
\hline 1 year old & 17 & 35.4 & 11 & 21.2 & 28 & 28 & \\
\hline 2 to 6 years old & 31 & 64.6 & 41 & 78.8 & 72 & 72 & \\
\hline TOTAL & 48 & 100 & 52 & 100 & 100 & 100 & \\
\hline Bottle content & & & & & & & 0.746 \\
\hline Warm milk & 15 & 31.3 & 17 & 32.7 & 32 & 32 & \\
\hline Warm milk with sugar & 6 & 12.5 & 9 & 17.3 & 15 & 15 & \\
\hline Warm milk with chocolate & 27 & 56.3 & 26 & 50.0 & 53 & 53 & \\
\hline TOTAL & 48 & 100 & 52 & 100 & 100 & 100 & \\
\hline $\begin{array}{l}\text { Age children started to perform oral hygiene } \\
\text { by themselves }\end{array}$ & & & & & & & 0.531 \\
\hline 1 to 3 years old & 16 & 33.3 & 18 & 34.6 & 34 & 34 & \\
\hline After 3 years old & 32 & 66.7 & 34 & 65.4 & 66 & 66 & \\
\hline TOTAL & 48 & 100 & 52 & 100 & 100 & 100 & \\
\hline Advising on toothbrushing & & & & & & & 0.427 \\
\hline Brush teeth lightly & 39 & 81.3 & 44 & 84.6 & 83 & 83 & \\
\hline Brush teeth strongly & 9 & 18.8 & 8 & 15.4 & 17 & 17 & \\
\hline TOTAL & 48 & 100 & 52 & 100 & 100 & 100 & \\
\hline Mother's monitoring during toothbrushing & & & & & & & ${ }^{*} 0.021$ \\
\hline No & 19 & 39.6 & 10 & 19.2 & 29 & 29 & \\
\hline Yes & 29 & 60.4 & 42 & 80.8 & 71 & 71 & \\
\hline TOTAL & 48 & 100 & 52 & 100 & 100 & 100 & \\
\hline Reason for no monitoring, if this is the case & & & & & & & 0.305 \\
\hline Lack of time & 29 & 60.4 & 35 & 67.3 & 64 & 64 & \\
\hline Thinks children can toothbrush by themselves & 19 & 39.6 & 52 & 32.7 & 36 & 36 & \\
\hline TOTAL & 48 & 100 & 52 & 100 & 100 & 100 & \\
\hline Strictness with toothbrushing schedule & & & & & & & 0.327 \\
\hline No & 10 & 20.8 & 8 & 15.4 & 16 & 16 & \\
\hline Yes & 38 & 79.2 & 44 & 84.6 & 82 & 82 & \\
\hline TOTAL & 48 & 100 & 52 & 100 & 100 & 100 & \\
\hline
\end{tabular}

\section{DISCUSSION}

Some studies attempted to reflect on the meaning of oral health for mothers or responsible persons regarding the oral hygiene of their children using a method of qualitative approach, because they wanted to verify perceptions, meanings, and understanding about the phenomenon studied (de Abreu et al., 2005; Domingues et al., 2008; Robles et al., 2010; Oliveira \& Forte). Other studies used a hybrid 
approach, meaning they performed a quantitative study to complement qualitative researches, aiming to measure and learn the distribution of some variables (Cabral et al.). The present study used only the quantitative observational approach, with the application of a questionnaire for mothers of children who attended a Basic Healthcare Unit, aiming to verify their knowledge and attitudes, and relate it to the experience they had with a dentist throughout their lives. Thus, a comparison was made with most studies that were similar in sample design, strategy, and size (Cruz et al.; Bardal et al., 2006; Campos \& Lima, 2006; Moura et al., 2007; Faustino-Silva et al.; Massoni et al., 2009; Campos et al.; da Silva \& Forte; da Silva et al., 2013).

Our results show that mothers know that dental caries is a disease and that its occurrence is related to diet habits. They visit the dental office motivated by oral health, even though most mothers feel anxious during treatment. It was noticed that satisfaction with the professional influences mothers on the oral hygiene habits adopted by their children regarding the use of dental floss and monitoring during toothbrushing.

The present study showed that the income of $21.4 \%$ of mothers is one minimum wage, $30 \%$ earn two to three minimum wages, and $20 \%$ earn about four minimum wages. This data is similar to other authors (Faustino et al.) who performed a study with 235 parents or responsible persons of preschool children from Porto Alegre, RS, Brazil. In contrast, two studies (Faustino-Silva et al.; Oliveira \& Forte) performed in Northeast Brazil showed that most mothers earn up to one minimum wage, thus reflecting the poor income distribution of the country.

Regarding occupation, most mothers (46.4\%) work outside the home, but a large portion of them monitor children during toothbrushing $(50.7 \%)$ and, in case they cannot do it, lack of time is the main justification (45.7\%). Similar to the present study, the authors of another research (Robles et al.; Oliveira \& Forte) reported that $80.4 \%$ of mothers monitors their children's hygiene. The present study also found that mothers correctly advise their children about tooth brushing, since $59.3 \%$ of mothers advises children to lightly brush their teeth, thus the example established by the family has a high impact on the development of oral health habits of children, which confirms other studies (Faustino-Silva et al.; Oliveira \& Forte). Most mothers are strict with tooth brushing schedule (58.6\%), and the example of mothers may generate good oral health for their children, since the maternal figure plays a major role in the healthcare of children and the mother is usually in charge of determining hygiene. Likewise, another study, mothers reported being strict with tooth brushing schedule, considering $57.3 \%$ of mothers did it during both day and night times (da Silva et al.). Discipline and family example are essential for establishing healthy habits in the development of children.

In the present study, $47.1 \%$ of mothers reported their children started performing oral hygiene by themselves from 3 years old forward. Another similar study reported that most mothers ( $57 \%$ ) believe that children between one and three years old could already perform their own oral hygiene, despite not having proper skills to do it (Faustino-Silva et al.). Differing from this study, another one showed that only $33.9 \%$ of mothers reported performing oral hygiene of their children soon after birth (Faustino-Silva et al.). On the other hand, in one study (Moura et al.), $48 \%$ of children performed oral hygiene aided by an adult. Tooth brushing techniques should be introduced as early as possible.

As for diet habits, when mothers were asked about the use of bottles, $51.4 \%$ reported their children were bottle-fed from two to 6 years old. Regarding the content of bottles, this study showed that $37.9 \%$ of mothers reported adding chocolate milk, thus noting that children were in contact with sugar from an early age. This lack of instruction regarding the early introduction of sugar was also observed in other studies (de Abreu et al.; Moura et al.; da Silva et al.). The effect of sugar on the oral cavity is the most important factor for the etiopathogenesis of caries, considering that diet influences the type and quantity of dental plaque, production of acids by microorganisms, and quantity and quality of salivary secretion. Studies show that socioeconomic condition may influence the knowledge about the influence of diet on oral health (Campos \& Lima). In the present study, $54.3 \%$ of mothers consider caries as a disease. Similar to this study, another one performed with 91 pregnant women from João Pessoa, PB, Brazil showed that $73.6 \%$ of them considers caries as a disease (Massoni et al.). This was similarly analyzed by another research, where mothers showed to be aware and informed regarding etiology and preventive methods for dental caries (Moura et al.); however, they were oriented by dentists during prenatal (Cabral et al.). 
Study show that mothers affirm the impossibility of children to grow up with no caries, justifying it as a "natural" course of life (Oliveira \& Forte). Other study (de Abreu et al.) report that mothers believe that caries is, for most individuals, an inevitable experience. These beliefs reflect the oral hygiene practices and conducts of mothers with their children. How people perceive the health-disease process directly influences their practices, and they may perceive the occurrence of an oral disease as something 'natural' rather than a disease (Bardal et al.).

A large portion of mothers also reported, in the present study, the use of dental floss in their children $(52.9 \%)$, thus showing good oral hygiene practice performed by mothers. This habit is potentially related to socioeconomic class, showing major differences between Class B and Class D (Cabral et al.; Campos et al.).

As for the satisfaction of the dentist reflected on the family, especially how it was characterized by mothers in the present study, $37.1 \%$ of mothers reported feeling satisfied and most of them had never quit a treatment $(42.9 \%)$. On the other hand, regarding the last visit, $44.3 \%$ of mothers reported visiting the dentist for over six months, which is similar to a study (Hanna et al., 2007) where most mothers visited the dentist for less than one year. As for the reason of dentist visits, the present study showed that most mothers $(44.3 \%)$ reported oral health as the main reason, different from studies that show pain as the main reason (Domingues et al.; Hanna et al.; Oliveira \& Forte).

When analyzing the feeling of mothers during treatment with a professional, our study showed that most mothers reported feeling anxious $(55.7 \%)$. Studies show that fear and pain are highly reported feelings (Domingues et al.). This shows that the feeling of mothers towards the professional is easily transferred to their children, resulting in children who are afraid of the dentist (Campos \& Lima).

The inferential analysis showed associations between satisfaction of the dentist, use of dental floss, and toothbrushing monitoring, thus identifying that mothers who encourage their children to use dental floss and monitor toothbrushing are the ones who feel satisfied with the dentist. This fact refers to a good previous experience with health professionals, verifying access to dental care. On the other hand, the challenge for mothers to feel satisfied with dental care results in low appreciation of oral health, creating low perception of need for dental treatment for their children. Authors (de Albuquerque et al., 2004; Moimaz et al., 2014), affirm that among sources of anxiety and fear perceived in pregnant women are pain and discomfort, among other factors, which is similar to the category used for the outcome variable of dissatisfaction (dentist fear, pain, and cost).

From the results found, learning some of the maternal perceptions is suggested, as in the present study, the presence and absence of satisfaction with the dentist and the oral health team of dental care units of cities, in order to plan strategies of health promotion and health education actions along with the community and groups of mothers who use the services. The implementation of a more open communication channel between professionals and service users is required so that proper information and orientation are given on the oral care of children, highlighting the importance of diet habits and the occurrence of dental caries.

\section{CONCLUSION}

It may be concluded that the mothers researched are in average 35 years old, married, work outside the home, and completed up to high school. Mothers know that dental caries is a disease and that its occurrence is related to diet habits, however they add chocolate milk and sugar in the bottle of their children. They advise and monitor their children to lightly brush their teeth and are strict with toothbrushing schedule.

Mothers feel satisfied with their dentist and it was the main reason to visit a professional is oral health; however, a large portion of mothers feel anxious during treatment. Satisfaction with the professional influences mothers on the oral hygiene habits adopted by their children regarding the use of dental floss and toothbrushing monitoring.

RIGO, L.; GNOATTO, M.; RODRIGUES, J. L. S. A.; VIEIRA, W. A.; PEREIRA-DE-OLIVEIRA, V. H. F. \& PARANHOS, L. R. Influencia de la saisfacción materna con el dentista en la salud oral del niño: Estudio transversal. Int. J. Odontostomat., 13(2):172-179, 2019.

RESUMEN: La infancia es un período de la vida en que el ser humano está en constante y progresivo desarrollo psicológico, físico y mental. La calidad de la higiene oral de otros miembros de la familia se va a reflejar directamente 
en las características y actitudes de los niños, aumentando significativamente la responsabilidad de la familia en la educación sobre higiene oral. El presente trabajo tuvo como objetivo observar la influencia que tiene la satisfacción de la madre con el cirujano dentista respecto a las acciones de la salud oral de los niños. Se trató de un estudio de tipo transversal, cuya muestra no probabilística contó con 100 madres de una ciudad del Sur de Brasil. A partir de un cuestionario elaborado para este fin y adaptado de investigaciones anteriores, las madres fueron entrevistadas en el período de enero a julio de 2015. Los resultados mostraron que la mayoría de las madres trabajaban fuera de la casa $(46,4$ $\%)$, pero acompañaban a su hijo durante el cepillado $(50,7$ $\%)$. La mayoría de ellas estaba conforme con la atención del cirujano dentista $(37,1 \%)$ y el mayor motivo de su búsqueda fue la salud oral (44,3\%). Se verificó que las madres que incentivaban el uso del hilo dental por parte de los hijos y que realizaban el acompañamiento durante el cepillado eran las madres que se sentían conformes con la atención del cirujano dentista $(p<0,05)$. Además de esto, las madres saben que la caries es una enfermedad y que su surgimiento tiene relación con la alimentación, pero igualmente le incorporaban cacao en polvo y azúcar a la mamadera de sus hijos. De esta manera, fue posible concluir que, la satisfacción con la atención del cirujano dentista influye a las madres en los hábitos de higiene oral adoptados por sus hijos, en lo relativo al uso del hilo dental y el cepillado dental.

PALABRAS CLAVE: dentistas, madres, salud oral, higiene oral, satisfacción del paciente.

\section{REFERENCES}

Bardal, P. A. P.; Olympio, K. P. K.; do Valle, A. A. L. \& Tomita, N. E. Cárie dentária em crianças como fenômeno natural ou patológico: ênfase na abordagem qualitativa. Cienc. Saude Colet., 11(1):161-7, 2006.

Cabral, M. C. B.; Santos, T. S. \& Moreira, T. P. Percepção das gestantes do Programa de Saúde da Família em relação à saúde bucal no município de Ribeirópolis, Sergipe, Brasil. Rev. Port. Saude Publica, 31(2):160-7, 2013.

Campos, J. A. D. B. \& Lima, N. A. Conhecimento de saúde bucal apresentado por mães segundo seu nível de escolaridade. Salusvita, 25(3):11-23, 2006.

Campos, L.; Bottan, E. R.; Birolo, J. B.; da Silveira, E. G. \& Schmitt, B. H. E. Conhecimento de mães de diferentes classes sociais sobre saúde bucal no município de Cocal do Sul (SC). Rev. SulBras. Odontol., 7(3):287-95, 2010.

Castilho, A. R.; Mialhe, F. L.; Barbosa, T. de S. \& Puppin-Rontani, R. $M$. Influence of family environment on children's oral health: a systematic review. J. Pediatr. (Rio J.), 89(2):116-23, 2013.

Cruz, A. A.; Gadelha, C. G.; Cavalcanti, A. L. \& Medeiros, P. F. Percepção materna sobre a higiene bucal de bebês: um estudo no hospital Alcides Carneiro, Campina Grande-PB. Pesq. Bras. Odontopediatr. Clin. Integr., 4(3):185-9, 2004.

da Silva, B. D. M. \& Forte, F. D. S. Access to dental treatment, mother's perception of oral health and intervention strategies in the city of Mogeiro, PB, Brazil. Pesq. Bras. Odontopediatr. Clin. Integr., 9(3):313-9, 2009. da Silva, R. A.; Nóia, N. B.; Gonçalves, L. M.; Pinho, J. R. \& da Cruz, M. C. Assessment of mothers' participation in a program of prevention and control of caries and periodontal diseases for infants. Rev. Paul. Pediatr., 31(1):83-9, 2013.

de Abreu, M. H. N. G.; Pordeus, I. A. \& Modena, C. M. Representações sociais de saúde bucal entre mães no meio rural de Itaúna (MG), 2002. Cienc. Saude Colet., 10(1):245-59, 2005.

de Albuquerque, O. M. R.; Abegg, C. \& Rodrigues, C. S. Percepção de gestantes do Programa Saúde da Família em relação a barreiras no atendimento odontológico em Pernambuco, Brasil. Cad. Saude Publica, 20(3):789-96, 2004.

Domingues, S. M.; de Carvalho, A. C. D. \& Narvai, P. C. Saúde bucal e cuidado odontológico: representações sociais de mães usuárias de um serviço público de saúde. Rev. Bras Crescim. Desenvolv. Hum., 18(1):66-78, 2008.

Faustino-Silva, D. D.; Ritter, F.; Nascimento, I. M.; Fontanive, P. V. N.; Persici, S. \& Rossoni, E. Cuidados em saúde bucal na primeira infância: percepções e conhecimentos de pais ou responsáveis de crianças em um centro de saúde de Porto Alegre, RS. Rev. Odontol. Cienc., 23(4):375-9, 2008.

Hanna, L. M. O.; Nogueira, A. J. S. \& Honda, V. Y. S. Percepção das gestantes sobre a atenção odontológica precoce nos bebês. RGO (Porto Alegre), 55(3):271-4, 2007.

Instituto Nacional de Geografia e Estatística (IBGE). Distribuição da população por sexo, segundo os grupos de idade Marau (RS). Brasilia, Instituto Nacional de Geografia e Estatística, 2010. Available from: <https://censo2010.ibge.gov.br/sinopse/ webservice/frm_piramide.php?codigo $=431180 \&$ corhomem $=$ 3d4590\&cormulher $=9 \mathrm{cdbf}>$.

Massoni, A. C. L. T.; Ferreira, J. M. S.; Silva, F. D. S. C. M.; Carvalho, L. F. P. C. \& Duarte, R. C. Conhecimento de gestantes sobre a saúde bucal dos bebês. Rev. Bras. Cienc. Saude, 13(1):41-7, 2009.

Moimaz, S. A.; Fadel, C. B.; Lolli, L. F.; Garbin, C. A.; Garbin, A. J. \& Saliba, N. A. Social aspects of dental caries in the context of mother-child pairs. J. Appl. Oral Sci., 22(1):73-8, 2014.

Moura, L. F. A. D.; de Moura, M. S. \& de Toledo, O. A. Conhecimentos e práticas em saúde bucal de mães que freqüentaram um programa odontológico de atenção materno-infantil. Cienc. Saude Colet., 12(4):1079-86, 2007.

Oliveira, W. F. \& Forte, F. D. S. Construindo o significado da saúde bucal a partir de experiência com mães. Pesq. Bras. Odontopediatr. Clin. Integr., 11(2):183-91, 2011.

Robles, A. C. C.; Grosseman, S. \& Bosco, V. L. Práticas e significados de saúde bucal: um estudo qualitativo com mães de crianças atendidas na Universidade Federal de Santa Catarina. Cienc. Saude Colet., 15(Supl. 2):3271-81, 2010.

Corresponding author:

Professor Luiz Renato Paranhos

Av. Pará, 1720, Bloco 2G, sala 1 Umuarama

Uberlândia-MG

BRASIL

E-mail: paranhos.Irp@gmail.com

Received: 18-11-2018

Accepted: 08-02-2019 